American Journal of Environmental Sciences 5 (2): 156-163, 2009

ISSN 1553-345X

(C) 2009 Science Publications

\title{
Using SWAT to Target Critical Source Sediment and Phosphorus Areas in the Wister Lake Basin, USA
}

\author{
${ }^{1}$ Philip R. Busteed, ${ }^{1}$ Daniel E. Storm, ${ }^{1}$ Michael J. White and ${ }^{2}$ Scott H. Stoodley \\ ${ }^{1}$ Department of Biosystems and Agricultural Engineering, Room $111 \mathrm{Ag}$ Hall, \\ Division of Agricultural Sciences and Natural Resources, \\ Oklahoma State University, Stillwater, OK 74078 \\ ${ }^{2}$ Vice President for Water Resources, Entrix, Inc., 13 Branch Street, \\ Suite 208, Methuen, MA 01844
}

\begin{abstract}
Problem statement: Wister Lake is located in the San Bois Mountains in southeastern Oklahoma, USA. The reservoir is primarily used as a water supply and flood storage to over 40,000 residents in the area. Due to high levels of phosphorus and sediment, Wister Lake is listed as a high priority basin for the State of Oklahoma. To help address these water quality problems, the Oklahoma Conservation Commission provided cost share funds for landowners in the basin to implement conservation practices. Approach: The objective of this study was to identify or target agricultural land that contributed disproportional pollutant losses, i.e. critical source areas. Results: Implementing conservation practice in these critical source areas allowed optimal placement conservation practices. The Soil and Water Assessment Tool (SWAT) model was used to identify critical source areas of phosphorus and sediment in the Wister Lake basin. SWAT predicted 57,000 metric tons a year of sediment and 84,000 kilograms a year of total phosphorus from upland areas in the basin. Eighty-five percent of the pollutant load originated from just 10\% of the basin. Conclusion/Recommendations: This allowed the OCC to identify and contact specific agricultural producers to recruit into their water quality program, which optimized the use of limited cost share funds.
\end{abstract}

Key words: Hydrologic modeling, BMP, cost share, water quality, GIS

\section{INTRODUCTION}

The water quality of Oklahoma's reservoirs, rivers and streams is being degraded by situation and excess algal growth. This excess growth is the result of an overabundance of nutrients. Phosphorus is often the limiting nutrient for algal growth. Phosphorus reduction is the most effective method of controlling algal growth in this region. Both phosphorus and sediment are ubiquitous in our environment, but different landscapes contribute these pollutants at different rates. Urban and agricultural land uses generate runoff with far higher phosphorus concentrations than similar areas under more natural conditions. These anthropogenic effects are primarily the result of phosphorus enrichment through fertilization and soil disturbance. The identification of areas which contribute excessive sediment and phosphorus is necessary if these water quality problems are to be mitigated ${ }^{[1]}$. Section 319 of the Clean Water Act is directed at controlling nonpoint sources primarily through education, with technical and financial assistance for landowners. Directing these limited resources at defined critical source areas delivers the greatest water quality improvement ${ }^{[2-4]}$.

The Wister Lake Basin is located in southeastern Oklahoma and southwest Arkansas, USA (Fig. 1). The basin area is approximately $2,400 \mathrm{~km}^{2}$ and the reservoir surface area is 2,950 ha. Water quality problems in Wister Lake and Poteau River stem primarily from excessive sediment and nutrient loads. The Poteau River is listed on the US Environmental Protection Agency (USEPA) 303 (d) list as being threatened or impaired by causes of metals, nutrients, situation, organic enrichment/dissolved oxygen, taste and odor, suspended solids and noxious aquatic plants. Wister Lake is listed for nutrients, situation, flow alteration, taste and odor and suspended solids. The 1996 Oklahoma Clean Lakes Study found the reservoir to be hyper-atrophic and to violate the State's turbidity standard for reservoirs ${ }^{[5,6]}$.

Corresponding Author: Daniel E. Storm, Department of Biosystems and Agricultural Engineering, Room 111 Ag Hall, Division of Agricultural Sciences and Natural Resources, Oklahoma State University, Stillwater, OK 74078 Fax: 405-744-6059 


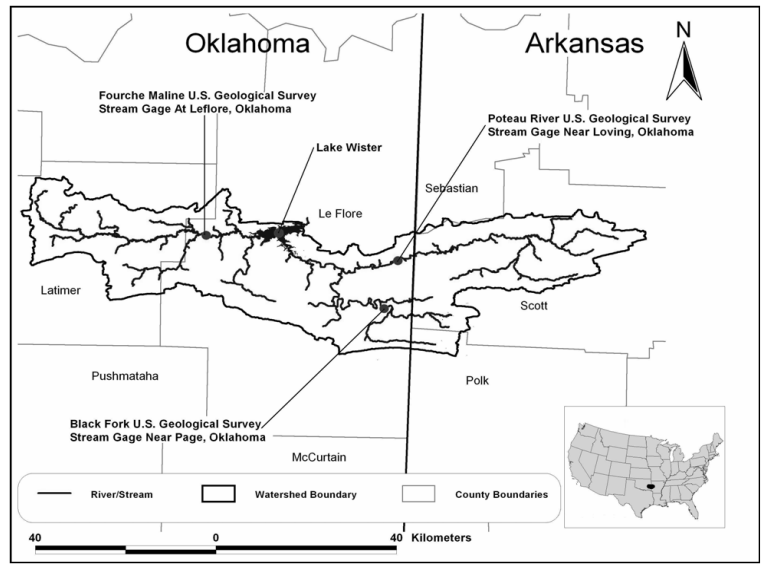

Fig. 1: Location of the Wister Lake Basin in southeast Oklahoma and southwest Arkansas, USA

The primary land covers within the basin are pasture and forest. In addition, there are over 275 poultry houses located in the Oklahoma portion of the basin, producing approximately $34,000 \mathrm{Mg}$ of poultry litter per year. Litter is bulky relative to its value, making it expensive to transport. Therefore, litter is generally applied to pastures near the poultry houses where it is produced $^{[7]}$. Since the litter is surface applied to pastures, it can be easily transported during storm runoff events. Litter is typically applied during the spring rainy season when almost a third of the total annual rainfall occurs. Spring rains in this region are produced by convective thunderstorms with high rainfall intensities which produce significant runoff and phosphorus loads to receiving water bodies.

The overall objective of this project was to identify critical source areas of phosphorus and sediment in the Oklahoma portion of the Wister Lake basin. Wister Lake and its tributaries were identified as being among the state's top priorities for nonpoint source implementation in the Oklahoma Section 319 Management and Cost Share Program. To more efficiently use the available funds, it was necessary to quantitatively identify or target areas with the highest potential for water quality improvement. The identification of critical source areas allowed optimal placement of Best Management Practices (BMPs) within a basin. Landowners within targeted areas were specifically recruited into cost share programs.

\section{MATERIALS AND METHODS}

The Soil Water Assessment Tool (SWAT) 2000 mode $^{[8]}$ was used to estimate total phosphorus and sediment loads to Wister Lake for the time period 1993-
2003. SWAT is a distributed parameter basin scale model developed by the US Department of Agriculture (USDA) Agricultural Research Service at the Grassland, Soil and Water Research Laboratory in Temple, Texas ${ }^{[9]}$. SWAT was used to locate areas with high average annual phosphorus and sediment losses.

SWAT model setup: SWAT is a distributed parameter model and thus data requirements are extensive. These requirements were met using an ArcView GIS interface, which generate model inputs using commonly available GIS data. These GIS data, topography, soils and land cover, were summarized by the interface and converted to a form usable by the SWAT model. Topography was defined by a US Geological Survey $30 \mathrm{~m}$ Digital Elevation Model (DEM), which was used to delineate the basin, define subbasin boundaries and define the stream network. The DEM was also used to calculate subbasin parameters, such as slope and slope length and to characterize stream network properties, i.e. channel slope, length and width. Soil characteristics were defined by SWAT using the Soil Survey Geographic (SSURGO) database ${ }^{[10]}$, the most detailed digital soil data available. To convert SSURGO data to a format compatible with SWAT, a SSURGO SWAT 2.0 extension for ArcView 3.X was used ${ }^{[11]}$. Land cover data were some of the most important GIS data used in the model. Land cover data defined the amount and distribution of forest, pasture, urban and rangeland within the Wister Lake Basin. These land covers yield different runoff, nutrient loads and erosion rates. A $30 \mathrm{~m}$ land cover data layer was created from Landsat 5 Thematic Mapper (TM) imagery collected on August 31 and September 9, 2004, which was obtained from the US Geological Survey (USGS) Earth Resources Observation and Science.

Land cover specific data, such as Soil Test Phosphorus (STP), management and fertilization practices from 1993-2003 were not widely available. STP for common land covers was derived from county level averages for the period 1994-2003. These data were obtained from the Oklahoma State University (OSU) Soil Testing Laboratory in Stillwater, Oklahoma, USA Fertilization and pasture management practices were based on a survey of local OSU Cooperative Extension Service (CES) and USDA Natural Resources Conservation Service employees. This survey detailed fertilizer applications in the basin along with common cattle stocking rates for fertilized and unfertilized pastures, common supplemental feeds and cattle grazing periods. Results from the survey indicated that ranchers in LeFlore and Scott Counties applied more poultry litter to their pasture lands while 
ranchers in Latimer County used very little $(<10 \%)$ poultry litter on their pastures. Some ranchers in Latimer County used some commercial fertilizer. With such differences in fertilizer type and application in the basin, pastures from the original land cover classification were split into two different categories. One category represented pastures in Latimer County where little to no litter was applied, which was due to limited availability. The second pasture category represented both Scott and LeFlore County, which had a far higher density of poultry houses, thus litter was more available. The nutrient content of the poultry litter was estimated to be $1 \%$ mineral nitrogen, $4 \%$ organic nitrogen, $0.4 \%$ mineral phosphorus and $1 \%$ organic phosphorus. Nutrient content was based on the distribution of bird types given in the Oklahoma Department of Agriculture Licensed Poultry Operators Database and nutrient content of each type of litter in the SWAT 2000 fertilizer database.

Observed daily precipitation and minimum and maximum temperatures were used in the SWAT model. Tabular temperature data (1/1/1993-12/31/2003) from thirteen climate stations from the National Oceanic Atmospheric Administration (NOAA) Cooperative Observation Network were used in the model. Due to variations in topography, which can influence rainfall patterns, we utilized Next Generation Radar (NEXRAD) precipitation data. The inclusion of NEXRAD in SWAT has been demonstrated to be an improvement in stream flow predictions over the use of COOP rainfall data alone ${ }^{[12]}$. SWAT compatible NEXRAD Weather Surveillance Radar 88D (WSR88D) derived precipitation estimates were incorporated into the SWAT model. Four km resolution WSR-88D Precipitation data were gage biased and archived by the Arkansas-Red Basin River Forecast Center (ABRFC). These data provide approximately 25 times more spatial resolution than available COOP stations.

Five point sources were located in the basin. Two of the five contained sufficient water quality data to estimate total phosphorus loads on an annual basis. They were the Tyson Foods Waldron Plant and the Waldron Waste Water Treatment Facility. The other three point sources were wastewater treatment facilities located in Wilburton, Oklahoma. Insufficient data were available at these locations to estimate an annual total phosphorus load. From data retrieved at USEPA's Permit Compliance System, we estimated approximately $6,000 \mathrm{~kg}$ year $^{-1}$ of total phosphorus enters the Poteau River from the Tyson Foods Waldron Plant and Waldron Waste Water Treatment Facility combined for the period 2003-2004. Only these two point sources were included in this analysis, although there were many other minor sources in the basin. These other minor sources, such as Confined Animal Feeding Operations (CAFOs), septic tanks and the Wilburton Waste Water Treatment facility, were considered negligible.

Total phosphorus and sediment loads, measured as total suspended solids, were estimated at three USGS stream gage locations: Poteau River at Loving, OK, Black Fork at Page, OK and the Fourche Maline at LeFlore, OK. The USGS DOS program LOADEST2 ${ }^{[13]}$ was implemented to estimate daily loads from observed concentration data. LOADERST2 was developed by Charles Crawford to estimate loads from discrete water quality samples and measured daily flow using the rating curve method.

In-stream nutrient processes may affect estimated sediment and total phosphorus concentrations as well as the temporal distribution of loads to Wister Lake. SWAT does not have a fully tested in-stream model and thus we disabled it in our study ${ }^{[14]}$. However, it should be noted that the absence of an in-stream model in SWAT is not critical for the purpose of identifying critical source areas of sediment and phosphorus.

Targeting: The SWAT targeting method chosen for this study was done on a Hydrologic Response Unit (HRU) level. A HRU is an area of a subbasin that contains a unique combination of land use, management and soil type ${ }^{[9]}$. Ninety-eight subbasins were created within the Wister Lake Basin, with each subbasins split into HRUs by SWAT. The SWAT land use [\%] over subbasin area threshold was changed from the default $20-0 \%$. This threshold determined the minimum percentage of any land cover in a subbasin that will become an HRU. The SWAT soil class [\%] over subbasin area was also reduced from its default value of $20-0 \%$. By reducing these thresholds to $0 \%$, all land covers and soil combinations in the basin were represented. A SWAT model with 98 subbasins and 5,846 HRUs with an average HRU size of 44 ha was developed.

A limitation of the SWAT 2000 ArcView 3.X interface was the ability to estimate slope for individual HRUs within a subbasin. SWAT estimated the same slope for all HRUs in a particular subbasin. In the Wister Lake Basin, forested areas tended to have steeper slopes than pastures and rangeland. This would likely resulted in pasture systems with steeper than observed slopes. To address this issue, each subbasin HRU slope and slope length were estimated based on the $30 \mathrm{~m}$ DEM, land cover and subbasin layout and incorporated in the model. 
In order to include all available NEXRAD data, the simulation period was from 1993-2003. A five year warm-up period was used in the targeting model to ensure proper initial aquifer levels, plant growth and soil moisture conditions. The model was calibrated and validated for stream flow, suspended solids and total phosphorus. The use of SWAT for targeting could have been done with an uncalibrated model, since the model was used in a "relative" mode and was not intended to predict absolute predictions loads or concentration. The model was used to locate areas with high average annual phosphorus and sediment loss. The actual magnitude is less important than the ratio of the loss at any given location to the basin average. However, by calibrating and validating the model we reduced the uncertainty in the model predictions.

\section{RESULTS}

SWAT model: The SWAT model was calibrated for 1993-2000 on a monthly and yearly basis for stream flow. At two of the locations, the Poteau River near Loving, OK and Black Fork near Page, OK, SWAT predictions were within $0.15 \mathrm{~m}^{3} \mathrm{sec}^{-1}$ of the observed stream flow (Table 1). The Poteau River observed and predicted results were 8.96 and $8.83 \mathrm{~m}^{3} \mathrm{sec}^{-1}$, respectively. The Black Fork was slightly better with an observed stream flow of $4.75 \mathrm{~m}^{3} \mathrm{sec}^{-1}$ compared to a SWAT prediction of $4.68 \mathrm{~m}^{3} \mathrm{sec}^{-1}$. The model tended to over-predicted stream flow on the Fourche Maline River with $9.61 \mathrm{~m}^{3} \mathrm{sec}^{-1}$ observed and SWAT predicted $10.4 \mathrm{~m}^{3} \mathrm{sec}^{-1}$.

The model was validated from 2001-2003. The model over-predicted stream flow at all three gauges. The last year of the validation period was a drought year in southeastern Oklahoma. Typically, this region received 52 inches of rainfall a year. In 2003, the region received 33 inches of rainfall, almost $40 \%$ below normal. SWAT has a tendency to over-predict base flow during drought years. However, the SWAT model predicted total monthly flow with Coefficient of
Determination and Nash-Sutcliffe efficiency ranging from 0.66-0.84 (Table 2).

The Nash-Sutcliffe efficiency was used as an indicator of goodness of fit ${ }^{[15]}$. There were no standards or a range of values for goodness-of-fit statistical parameters that adjudge the model performance as acceptable ${ }^{[16]}$. Ramanarayanan et al. ${ }^{[17]}$ suggested values of goodness-of-fit statistics for determining the acceptable performance of the APEX model. They indicated that values close to zero for a Correlation Coefficient and/or the Nash-Sutcliffe coefficient indicated the model performance was unacceptable or poor. They judged the model performance as satisfactory or acceptable if the monthly Correlation Coefficient was $>0.5$ and the monthly Nash Sutcliffe coefficient was $>0.4$. Santhi et al. ${ }^{[18]}$ assumed a monthly Nash-Sutcliffe coefficient $>0.5$ and a monthly Coefficient of Determination $\left(\mathrm{R}^{2}\right)>0.6$ indicated acceptable model performance when calibrating SWAT. However, acceptable statistical measures are project specific.

The SWAT model often over-predicted sediment in the Wister Lake Basin but always underestimated total phosphorus (Table 3). The relative error at the Poteau River site was $-25 \%$ for sediment and $25 \%$ for total phosphorus. SWAT under-predicted both sediment (relative error of 17\%) and total phosphorus (relative error of 84\%) at the Black Fork station. For the Fourche Maline site, SWAT over-predicted sediment with a relative error of $-130 \%$, but did a reasonable job in predicting total phosphorus with a relative error of $7 \%$. The SWAT model was validated for annual total phosphorus and sediment loads for the period January 2001-December 2003. The SWAT model predicted total phosphorus and sediment loads within $15 \%$ of LOADEST2 estimates at the Poteau River near Loving site (Table 4). SWAT tended to under-predict total phosphorus at the Black Fork gage with a relative error of $73 \%$ and slightly over-predicted sediment with a relative error of $-20 \%$.

Table 1: Lake Wister Basin monthly SWAT model hydrologic calibration results for flow at three stream gages for the period 1/1993-12/2000

\begin{tabular}{llllll}
\hline Site name & $\begin{array}{l}\text { Observed flow } \\
\mathrm{m}^{3} \mathrm{sec}^{-1}\end{array}$ & $\begin{array}{l}\text { Predicted flow } \\
\mathrm{m}^{3} \mathrm{sec}^{-1}\end{array}$ & $\begin{array}{l}\text { Relative } \\
\text { error }\end{array}$ & $\begin{array}{l}\text { Nash-sutcliffe } \\
\text { efficiency }\end{array}$ & $\begin{array}{l}\text { Coefficient of } \\
\text { determination }\end{array}$ \\
\hline Poteau River Loving, OK & 8.27 & 11.3 & $-37 \%$ & 0.75 & 0.81 \\
Black Fork at page, OK & 4.20 & 5.80 & $-38 \%$ & 0.66 & 0.78 \\
Fourche Maline at Leflore, OK & 8.69 & 11.8 & $-36 \%$ & 0.63 & 0.72 \\
\hline
\end{tabular}

Table 2: Lake Wister Basin monthly SWAT model hydrologic validation results for flow at three stream gages for the period 1/2001-12/2003

\begin{tabular}{llllll}
\hline Site name & $\begin{array}{l}\text { Observed flow } \\
\mathrm{m}^{3} \mathrm{sec}^{-1}\end{array}$ & $\begin{array}{l}\text { Predicted flow } \\
\mathrm{m}^{3} \mathrm{sec}^{-1}\end{array}$ & $\begin{array}{l}\text { Relative } \\
\text { error }\end{array}$ & $\begin{array}{l}\text { Nash-sutcliffe } \\
\text { efficiency }\end{array}$ & $\begin{array}{l}\text { Coefficient of } \\
\text { determination }\end{array}$ \\
\hline Poteau River Loving, OK & 8.27 & 11.3 & $-37 \%$ & 0.75 & 0.81 \\
Black Fork at Page, OK & 4.20 & 5.80 & $-38 \%$ & 0.66 & 0.78 \\
Fourche Maline at Leflore, OK & 8.69 & 11.8 & $-36 \%$ & 0.63 & 0.72 \\
\hline
\end{tabular}


Am. J. Environ. Sci., 5 (2): 156-163, 2009

Table 3: Lake Wister Basin average annual SWAT model calibration results for total phosphorus and sediment at three stream gages for the period 1/1993-12/2000

\begin{tabular}{llll}
\hline Site name & & Total phosphorus kg ha $^{-1}$ \\
Poteau River atLoving, OK & & Sediment & Nonpoint sources only \\
& & Mg year $^{-1}$ & 52,000 \\
& Observed & 20,000 & 33,000 \\
Black Fork at Page, OK & Predicated & 25,000 & $37 \%$ \\
& Relative Error & $-25 \%$ & 8,000 \\
& Observed & 1,800 & 1,300 \\
Fourche Maline at Leflore, OK & Predicated & 1,500 & $84 \%$ \\
& Relative Error & $17 \%$ & $25 \%, 000$ \\
& Observed & 10,000 & 27,000 \\
\hline
\end{tabular}

Table 4: Lake Wister Basin average annual SWAT model validation results for total phosphorus and sediment at three stream gages for the period $1 / 2001-12 / 2003$

\begin{tabular}{|c|c|c|c|c|}
\hline \multirow[b]{2}{*}{ Site name } & & \multirow[b]{2}{*}{$\begin{array}{l}\text { Sediment } \\
\text { Mg year }^{-1}\end{array}$} & \multicolumn{2}{|c|}{ Total phosphorus, $\mathrm{kg} \mathrm{ha}^{-1}$} \\
\hline & & & Nonpoint sources only & Point and nonpoint sources \\
\hline \multirow[t]{3}{*}{ Proteau River at Loving , OK } & Observed & 38,000 & 48,000 & 48,000 \\
\hline & Predicted & 36,000 & 49,000 & 55,000 \\
\hline & Relative error & $5 \%$ & $-2 \%$ & $-15 \%$ \\
\hline \multirow[t]{3}{*}{ Black Fork at Page,OK } & Observed & 25,00 & 73,00 & \\
\hline & Predicted & 3,000 & 2,000 & NA \\
\hline & Relative error & $-20 \%$ & $73 \%$ & \\
\hline \multirow[t]{3}{*}{ Fourche Maline at Leflore,OK } & Observed & 10,000 & 34,000 & \\
\hline & Predicted & 22,000 & 29,000 & NA \\
\hline & Relative error & $-120 \%$ & $15 \%$ & \\
\hline
\end{tabular}



Fig. 2: Targeted areas for total phosphorus in the Wister Lake Basin as predicted by SWAT

Similar to the calibration period at the Fourche Maline gage, SWAT over-predicted sediment and was relatively close to the total phosphorus load with a relative error of $15 \%$. For the purposes of targeting, these validation results were acceptable.

Targeting: HRUs were ranked from high to low based on their SWAT predicted sediment and phosphorus loss. Some HRUs continually ranked high for both constituents. These HRUs were located on steeps slopes

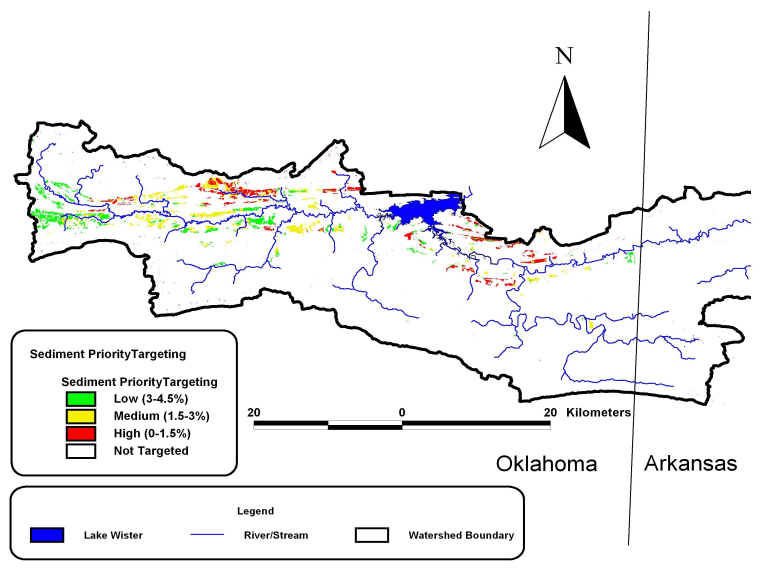

Fig. 3: Targeted areas for sediment in the Wister Lake Basin as predicted by SWAT

and had high surface runoff soil types. Ranking was established to identify the $1.5,3.0$ and $4.5 \%$ of the basin with the highest total phosphorus and sediment losses (Fig. 2 and 3).

Almost $80 \%$ of the basin was forested with relatively small phosphorus and sediment loads. Eightyfive to ninety percent of sediment and total phosphorus load originated from only $10 \%$ of the basin (Fig. 4 and 5). Pastures and bare soil contributed the majority of sediment and total phosphorus loads. Upon inspection 
Am. J. Environ. Sci., 5 (2): 156-163, 2009

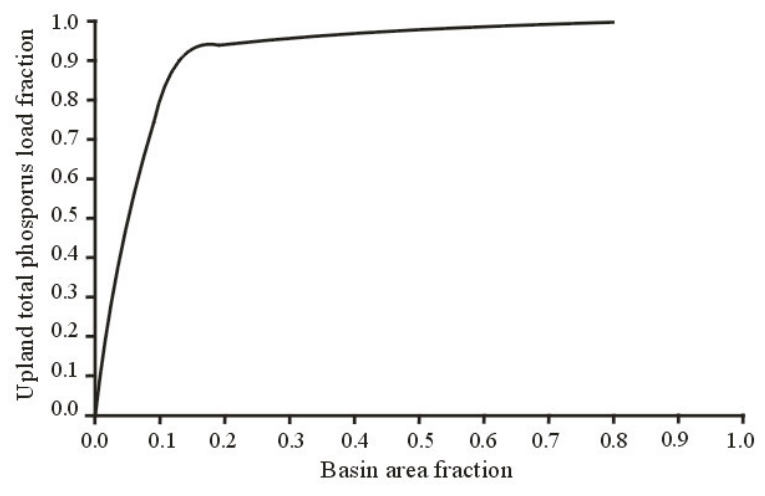

Fig. 4: SWAT predicted fraction of total phosphorus load from upland sources versus the fraction of Lake Wister Basin area

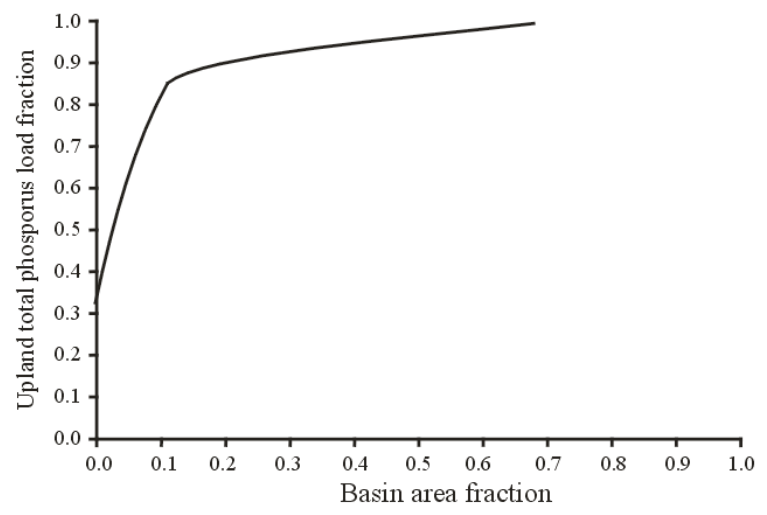

Fig. 5: SWAT predicted fraction of basin sediment load from upland sources versus the fraction of Lake Wister Basin area

of aerial photography, the bare soil land cover classification comprised several different land uses ranging from natural gas pads to bare fields. The shape of the curves (Fig. 4 and 5) was different than previous curves seen in other Oklahoma basins because most of the basin was forested ${ }^{[19,20]}$.

\section{DISCUSSION}

One of Oklahoma Conservation Commission's (OCC's) primary missions was the identification, prioritization and management of streams, rivers and reservoirs impaired from nonpoint source pollution. As a result, OCC created the Oklahoma Nonpoint Source Working Group consisting of landowners, environmental groups, American Indian tribes and federal, state and local government agencies. A difficult task of the group was the identification of areas within priority basins that would benefit from cost share funds and technical assistance. The use of SWAT for targeting purposes was an excellent solution to aid these groups in maximizing their limited resources.

A large portion of the Wister Lake Basin was forest land $(\sim 80 \%)$, followed by pastures $(\sim 18 \%)$, water $(>1 \%)$ and urban $(<1 \%)$. Pasture lands were the primary source of sediment and nutrients in the basin. The Wister Lake Basin sediment load from upland areas, as predicted by SWAT, was $57,000 \mathrm{Mg}_{\text {year }}{ }^{-1}$. SWAT predicted a total phosphorus load of $84,000 \mathrm{~kg}$ P/yr. Although these predictions were close to LOADEST2 estimates, with an in-stream nutrient model SWAT predictions may improve for both sediment and nutrients. Pastures had high sediment and total phosphorus loads for various reasons. One explanation is the presence of soils in Hydrologic Soil Groups C and D. The occurrence of these soil groups resulted in high surface runoff and soil erosion ${ }^{[21]}$. It was also important to note that there were no pastures with Hydrological Soil Group A. Group A soils have lower Curve Numbers and thus less surface runoff compared to Groups $\mathrm{C}$ or D. In addition, the application of poultry litter increases total phosphorus loss since the surface application increases the availability of phosphorus for surface runoff.

Although in-stream processes were likely significant, these processes were not properly accounted for, which added to the uncertainty to the predictions. Also, SWAT does not predict sediment bed load and our model also did not account for various impoundments located on the streams. Impoundments can play a crucial role in sediment/nutrient movement and transformations in a stream channel by trapping sediment and sediment-bound nutrients. For the purposes of targeting critical source areas, however, the calibration results were acceptable because this method of targeting relies upland processes (i.e., surface erosion, runoff) and not in stream processes.

\section{CONCLUSION}

Areas with disproportionately high pollutant losses, i.e., critical source areas, have been widely recognized as priority areas for the control of nonpoint source pollution. The identification and evaluation of critical source areas at the basin scale allow state and federal programs to implement conservation practices where they are needed most. Conservation practices implemented in these areas are more effective because they have the opportunity to treat more pollutant and thus will improve the effectiveness of these water quality programs. The SWAT model efficiently identified critical source sediment and phosphorus areas 
within the Wister Lake basin. This allowed the OCC to identify and contact specific agricultural producers to recruit into their water quality program. This methodology is directly applicable to any basin that is primarily agricultural. The time and resources required to conduct this type of modeling study is minimal compared to the monies used to administer and implement cost share programs.

\section{ACKNOWLEDGMENT}

We would like to thank the Oklahoma Conservation Commission and the U.S. Environmental Protection Agency Region VI for their funding and support of this project. We would like to express our gratitude towards the US Department of Agriculture Natural Resources Conservation Service in Poteau, Oklahoma and the Oklahoma State University County Extension Offices in Latimer and LeFlore Counties for all their help. We would also like to thank AMEC Earth and Environmental Inc. for developing the land cover, which was a crucial portion of this project.

\section{REFERENCES}

1. Sharpley, A., 1999. Agricultural Phosphorus, Water Quality and Poultry Production: Are They Compatible? Poult. Sci., 78: 660-673. http://ps.fass.org/cgi/content/abstract/78/5/660

2. Djodjic, F., H. Montas, A. Shirmohammadi, L. Bergstrom and B. Ulen, 2002. A decision support system for phosphorus management at a watershed scale. J. Environ. Qual., 31: 937-945. http://www.ncbi.nlm.nih.gov/pubmed/12026098

3. Sharpley, A., J.L. Weld, D.B. Beegle and P. Kleinman, 2003. Development of phosphorus indices for 4 nutrient management planning strategies in the United States. J. Soil Water Convers., 58: 137-152. http://www.jswconline.org/content/58/3/137.full.pdf

4. White, M.J., D.E. Storm and S. Stoodley, 2003. A strategy for using SWAT to target critical sediment source areas. Proceedings of the 2nd Conference on TMDL Environmental Regulations, Nov. 8-12, ASAE Publication, Albuquerque, New Mexico USA., pp: 543-549.

http://asae.frymulti.com/abstract.asp?aid $=15612 \& \mathrm{t}=2$

5. Noble Jobe, 1996. Diagnostic and feasibility study of tenkiller lake: Phase I of a clean lakes projectfinal report. http://www.owrb.ok.gov/studies/reports/reports_pd f/TenkillerPhase1.pdf
6. Oklahoma Water Resources Board, 2003. Lake Wister Water Quality, Bathymetry and Restoration Alternatives-Final Report. http://www.worldcat.org/wcpa/ow/54886253

7. Storm, D.E., M.J. White, B.E. Haggard and M.D. Smolen, 2006. Illinois River Upland and Instream Phosphorus Modeling-Final Report. www.storm.okstate.edu/reports/Illinois_River_Reo rt_\%206-28-2006.pdf

8. Arnold, J.G., R. Srinivasan, R.S. Mittiah and J.R. Williams, 1998. Large area hydraulic modeling and assessment: Part I-model development. J. Am. Water Resour. Assoc., 34: 73-89. DOI: $10.1111 /$ j.1752-1688.1998.tb05961.x

9. Neitsch, S.L., J.G. Arnold and J.R. Williams, 2001. Soil and water assessment tool user's manual version 2000. http://www.epa.gov/waterscience/basins/basinsv3.htm

10. US Department of Agriculture, 2007. Soil Survey Geographic Data Base (SSURGO), Version 2, Minnesota.

http://www.lmic.state.mn.us/chouse/metadata/ssurg o.html

11. Peschel, J.M., P.K. Haan and R.E. Lacey, 2003. A SSURGO pre-processing extension for the ArcView soil and water assessment tool. ASAE Paper No. 032123. http://lcluc.tamu.edu/ssurgo/2003.ASAE.032123.p aper.pdf

12. White, M.J., D.E. Storm and S. Stoodley, M.D. Smolen, 2003. Modeling the lake eucha basin with SWAT 2000. Proceedings of the TMDL Environmental Regulations Conference, Nov. 8-12. ASAE Publication, Albuquerque, New Mexico USA., pp: 536-542. http://asae.frymulti.com/abstract.asp?aid $=15611 \& \mathrm{t}=2$

13. Crawford, G. Charles, 1996. Estimating Mean Constituent Loads in Rivers by the Rating Curve and Flow Duration, Rating Curve Methods. Indiana University, Bloomington, Indiana, Ph.D. Dissertation, pp: 245.

14. Houser, J.B. and L.M. Hauck, 2002. Analysis of instream water quality component of Soil Water Assessment Tool (SWAT). Proceedings of the TMDL Environmental Regulations Conference, Mar. 11-13, ASAE Publication, Albuquerque, New Mexico USA., pp: 52-55. http://asae.frymulti.com/abstract.asp?aid=7528\&t=2

15. Nash, J.E. and J.V. Sutcliffe, 1970. River flow forecasting through conceptual models 1. A discussion of principles. J. Hydrol., 10: 282-290. DOI: 10.1016/0022-1694(70)90255-6 
16. Loague, K. and R.E. Green, 1991. Statistical and graphical methods for evaluating solute transport models: overview and application. J. Contaminant. Hydrol., 7: 51-73. DOI: 10.1016/01697722(91)90038-3

17. Ramanarayanan, T.S., J.R. Williams, W.A. Dugas, L.M. Hauck and A.M. S.McFarland, 1997. Using APEX to identify alternative practices for animal waste management. Proceeding of the ASAE Annual International Meeting, Aug. 10-14, 2950 Niles Road, St. Joseph, MI., pp: 1-36. http://www.brc.tamus.edu/media/13043/ramana.pdf

18. Santhi, C., J.G. Arnold, J.R. Williams, W.A. Dugas, R. Srinivasan and L.M. Hauck, 2001. Validation of the SWAT Model on a Large River Basin with Point and Nonpoint Sources. J. Am. Water Resour. Assoc., 37: 1169-1188.

http://cat.inist.fr/?aModele $=$ afficheN\&cpsidt $=1408$ 0260
19. Storm, D.E., M.J. White and S. Stoodley, 2003. Stillwater creek modeling and land cover classification final report. http://storm.okstate.edu/reports/Stillwater\%20Cree k\%20report\%204_1_2003\%20-\%20Final.pdf

20. Storm, D.E., M.J. White and P.R. Busteed, 2005. Targeting high phosphorus loss areas in the spavinaw creek basin final report. http://storm.okstate.edu/reports/Spavinaw\%20Targ eting\%2011-2-2005\%20FINAL.pdf

21. Haan, C.T., B.J. Barfield and J.C. Hayes, 1994. Design Hydrology and Sedimentation for Small Catchments. Academic Press Inc., San Diego, California, ISBN: 10: 0123123402, pp: 588. 